\title{
Research and Construction of Dynamic Evaluation System for College Japanese Linguistics Course
}

\author{
Wei Zou \\ School of Foreign Studies, Xi'an University,710065
}

Keyword: College Japanese; Linguistics; Course; Evaluation system

\begin{abstract}
Japanese Linguistics is an important port of College Japanese Course and the good Japanese linguistics teaching has become the priority among priorities in Japanese teaching. Currently, the Chinese colleges and universities have different teaching level of Japanese Linguistics and have various problems. If a dynamic evaluation system applicable to the college Japanese Linguistics Course is established, it will have significant reference and supporting impact not only on the Japanese linguistics teaching itself, but also on the establishment of overall teaching evaluation system in colleges and universities.
\end{abstract}

\section{Introduction}

Japanese Linguistics is a course that the knowledge of modern Japanese Linguistics is taught in a systematic way to stimulate students' interest in learning this course and so as to improve students' ability to learn the Japanese language. In most of colleges and universities, Japanese Linguistics is a required course that university students specialized in Japanese must take. It closely combines pragmatics, phonetics and academic writing and at the same time provides certain theoretical foundation for the study of other disciplines in some aspects.

Japanese Linguistics has made remarkable achievements in many aspects through the construction and development for these years. With the economic development and social progress, China has increasingly high requirements for foreign language talents. Under the great background of quality education, due to the restraints of system and traditional ideas, the teaching reform of Japanese Linguistics in colleges and universities has been lingering, and its teaching focuses on theory, but not practice, and thus outmoded teaching method and such disadvantages are increasingly exposed. It not only greatly reduces the students' interest in learning this course, but also triggers a series of teaching problems. Faced with various problems before us, should we stand still and refuse to make progress, shrink back from difficulties or reform with keen determination and face the difficulty? I think, the sense of mission and the sense of responsibility as an educator has given us the right answer.

The dynamic evaluation system of course refers to a process to evaluate the course value through certain technical means and technical index research, for the purpose of enhance students' enthusiasm and initiative of to study and facilitate teachers to carry out the teaching practice in a creative way. The dynamic evaluation system of course is a multi-link, diversified and quantitative system based on the relations between students and teachers. The dynamic evaluation system of College Japanese Linguistics Course is designed and constructed for the problems existing in current College Japanese Linguistics teaching, and it is of high pertinence.

\section{Teaching Status and Existing Main Problems}

The overall teaching effect of College Japanese Linguistics Course in China is not so desirable. Teachers during teaching activities still follow traditional teaching mod and rigid and tedious teaching methods to generally make students repressed and often lack the enthusiasm to learn the course. In the Japanese Linguistics Course teaching, the lecture of theoretical knowledge takes up most of part of the teaching contents and there is less training on student's language competence. The evaluation mode of student's learning effect has not been adjusted for many years, and the performance but not ability is focused on, without scientific and improved evaluation mechanism 
matching with learning. All these phenomena are not by chance, but a complex consisting of historical, mechanical and concept factors; its reasons can be concluded as follows:

Unidirectionality of feedback system. Japanese Linguistics is a highly informative course. According to the investigation of related institution, main reason for most of students having poor interest in this course is improper teaching method carried out by teachers, followed by too outmoded teaching contents. This phenomenon does not happen in one day; but one of reasons for why it is protracted is the dominant role of teachers in the teaching activities. In traditional teaching model, teachers are dominant in the course setting, classroom progress, teaching content, examination and evaluation...these reflect a unidirectional feedback conduction system, and students are totally under the position of passive acceptance. In quality education, we advocate the student's personality cultivation and advocate fostering students' ability to independently learn. However, current education teaching status fails to fundamentally support the demands of modernization construction for the talent training and sometimes even presents the situation of drifting away.

Oneness of evaluation system. We have been shouting the slogan of quality education for many years, but what is its effect? Apart from other aspects, but only on account of the evaluation system, we have not yet basically got rid of the examination-focused outmoded teaching ideas. Every student has their own characters, and if the education is stereotyped to obtain fruitful teaching achievement, then human beings had stopped exploring the teaching means and teaching methods. Teaching students in accordance of their aptitude and varying with the individual should not only engage in idle theorizing. Currently, the teaching evaluation of Japanese Linguistics Course is still carried out by means of summative assessment, that is, examination and such single test to judge students' learning result and teachers' teaching quality by virtues of performance and to take the examination simply as evaluation. Under such summative assessment, what teachers teach is tested and students learn what will be tested; the difficulty of assessment knowledge is limited, but only reappearing the linguistic terminology, theoretical understanding and memory, with less thinking examination and the application and expansion ability of linguistics knowledge basically ignored; therefore, it is static evaluation, Although the final performance includes $20 \%-30 \%$ usual performance, the usual performance evaluation is rather informal and sometime it is even judged according to students' attendance. Such relatively isolated and static course evaluation method fails to truthfully and comprehensively reflect student's mastering of knowledge, fails to scientifically and objectively assess students' practical ability, and it not only makes the evaluation reliability and validity error and fails to have good impact on the course study, but also ignores the subjectivity and initiative of students in learning to a great extent and fails to effectively foster student's ability.

Rigidity of teacher's knowledge system. Teachers of College Japanese Linguistics should regularly reflect on their own teaching and be good at finding the difference in their own knowledge system and continuously update them. Teachers need communicate with each other and constantly enrich their own knowledge reserve with the latest theory. They should temper their ability to convert abstract knowledge point into accessible examples and express it. Young students, as a special group, are very curious about new things and have the desire for exploration. For this reason, they are often at the forefront of the scientific, technological and academic exploration. Teachers' teaching content should follow up the pace of times, but not follow the beaten track or become as dry as dust, or it is very difficult to attract young students' appetite for knowledge in teaching.

\section{Theoretical Research on Construction of Dynamic Evaluation System}

In the teaching of College Japanese Course, the teaching evaluation is taken as an important link; it is not only an important means that teachers get to know students' learning condition, improve teaching strategy and promote effective teaching, but also a sign that students study independently and it will facilitate students to define their own learning task, adjust the learning progress, improve the learning method and finally achieve good learning effect. Therefore, it is critical to comprehensively, objectively, scientifically and accurately evaluate the system in order to achieve the teaching objectives. Related documents of the Ministry of Education specify that the evaluation 
on students' learning is divided into formative evaluation and summative evaluation and stress the value orientation of the "process" and "development". That is, the College Japanese teaching should focus on students' learning process in evaluation and it should become an important means from measuring students' learning effect to promoting the bi-directional development and comprehensive development of teachers and students; thus, it is necessary to establish dynamic and diversified evaluation system, focus on the practice process and ability evaluation in order to achieve the diversification of subject and way and the multilevel of evaluation function and facilitate students to effectively learn.

As the dynamic system theory is introduced into the field of Applied Linguistics, the language development can be considered as a dynamic system, providing a new perspective for the construction of demand analysis model of Japanese Course. Based on the dynamic system theory, the Japanese learning process is neither a pure cognitive mentality process, nor completely concluded as a social culture process, but a dynamic transfer process of system status under the influence of multiple input factors. Under such circumstance, the purpose of demand analysis on Japanese Linguistics Course is not simply to determine students' ability and expected demand point desired to be reached, or understand the linear difference between students' expectation and the reality, but to analyze and represent the status variable of students' Japanese level and the dynamic relation between students' current Japanese level represented by the status variable and the targeted language level, input variable (factor), status variable and output variable affecting students' learning process, and to finally establish the learning status change model of targeted students. Based on such model, the objective of course setting is to enable students to transfer from the initial status to the targeted status within the shortest time through changing the values of some input variables affecting the learning status. Based on the dynamic system theory, the learning of Japanese Linguistics can be taken as a dynamic system including students, teachers and corresponding learning environment.

The key point of the dynamic evaluation system is the interactivity which is primary and the most fundamental to break the master-slave relation in previous learning and it makes teaching and learning reach a dynamic balance. Teachers should make efforts to change outmoded ideas in thinking, define students' dominant position and play their major role in stimulating students' learning interest and fostering their innovation ability and critical thinking skills in classroom. Students in classroom should be given more initiative; they are not pure knowledge receivers, but the course participants. They can talk with teachers about the course planning, course setting and even select certain teaching method. Teachers and students learn from each other in mutual emulation, help each other forward and complement each other during teaching.

Construction of scientific and reasonable formative evaluation model. Formative evaluation records break single score evaluation mechanism, but focuses on students' daily cultivation and daily learning habit. It generally consists of students' study archive, classroom observation record and mutual evaluation of students and teachers' evaluation. Study archives record students' every progress in learning. It is a collection of students' representative homework, reading report, classroom presentation record, reflection report and such things that can represent students' progress and performance. The students' learning portfolio provides parents and teachers with students' learning and progress record and enables teachers to know the learning condition of each student, students' problems in Japanese learning and solve problems. At the same time, under teachers' guidance, students establish their own learning portfolio, not only knowing their one progress, learning condition, their own strength and weakness at this stage, but also helping them to determine their own striving direction and promoting them to produce a sense of responsibility for their own study; classroom observation refers to the observation of students' performance and response in participation in the classroom teaching activity. Teachers can list some basic items, such as the times of answering questions, answer accuracy and completeness and the participation in group activity as the criteria for examination or evaluation, so as to record students' classroom performance and progress change within a period of time. Classroom observation can not only evaluate whether students learn the knowledge that they should know and observe students' interest 
in the learning material, but also helps teacher to find the problems in teaching. Teachers can analyze the phenomenon observed by him through survey and survey, and comprehensively and objectively obtain the teaching and learning information, in order to guide future teaching; students reflect on their own learning target, learning process and learning strategy through self-evaluation and can check their own staged language knowledge and pragmatic competence level. It will facilitate them to find the problems in learning and accordingly make adjustment based on their own conditions. It can not only foster students' ability to correctly evaluate themselves, but also avoid teachers' direct evaluation eroding students' pride and self-confidence. In addition to self-evaluation, teachers should also encourage students to actively exchange with other students. Mutual evaluation and exchange will facilitate them to mutually learn from each other, provide feedback and learn from others' strong points to offset their own weakness.

Dynamic adjustment of education content. College education is the last stage of current education system of China, a link connecting the education and the society, and students will also finish the transformation from "student" to "social man" in colleges and universities. Therefore, compared with teaching objectives and teaching tasks of primary and middle schools, the actual teaching objectives of college courses seem relatively complicated, and Japanese Linguistics is no exception. Teaching objectives in middle schools are relatively simple, often focus on the senior high school entrance examination, college entrance examination and various examinations, and students' learning requirements and learning targets are also relatively simple. But when students are admitted to colleges and universities, they have their own learning objectives and requirements for the college courses based on their own conditions and future career orientation. Therefore, College Japanese teaching should focus on the demand of the society for the Japanese proficiency, narrow the gap between teaching and demand and attach importance to strengthening students' cultivation and improvement in Japanese proficiency. If the learners' learning requirement and learning objective are ignored, but only the teaching objective is imposed on students based on teachers' understanding of the course and what book says is repeated, it will get half the result with twice the effort and fail to achieve good effect, and generally it is difficult to for students to accept such teaching.

\section{References}

[1] CUI Zhenlin. Methods and Skills to Improve Japanese Reading Ability [J], Journal of Yanbian Education College, No. 6, 2007.

[2] SHAN Tianhong. A Brief Discussion on Japanese Reading Teaching in Higher Vocational College [J], Journal of Wuxi Institute of Technology, No. 1, 2007

[3] LI Hong. JLPT Characteristics and Examination Countermeasures [J], Journal of Jiaozuo Institute of Technology (Social Science), No. 02, 2004.

[4] YANG Xiaohu \& ZHANG Wenpeng. Metacognition and Foreign Language Reading Understanding [J], Journal of China University of Mining \& Technology(Social Science), No. 03, 2001.

[5] CHEN Changming. Orthographic Awareness and Phonological Awareness of Illiteracy and Its Development in Reading Ability Acquisition [D], Southwest University; 2010.

[6] Zhao Guiqin. Application of "Reading Strategy" in Reading Teaching of Japanese Major [J], Journal of Yuncheng University, No. 2, 2007.

[7] CUI Gang. Theory and Practice of Grammar Teaching [J]. Foreign Language Teaching \& Research in Basic Education, 2007.

[8] HU Weiwei. New Idea of Grammar Teaching Model of College Japanese [J]. Journal of Southwest Agricultural University(Social Science Edition), 2011.

[9] XU Wei. Reflections on College Japanese Teaching [J], Journal of Creative Education, April, 2007.

[10] WANG Yanying. Exploration of Comprehensive Teaching Model of College Japanese [J]. Journal of Japanese Language Study and Research, No. 1, 2000. 
[11]HU Weiwei. New Idea of Grammar Teaching Model of College Japanese [J]. Journal of Southwest Agricultural University(Social Science Edition), No. 7, 2011.

[12] HUO Liang. Exploration of Teaching Reform in College Japanese [J]. Exam Weekly, No. 37, 2011.

[13] YANG Ye. Significance of Grammar Teaching in College Japanese Teaching [J]. China Education Innovation Herald, No. 6, 2010. 